\title{
IJPHN
}

\section{Relationship of Age, Gender, and History of Comorbid Diseases in TB Patients toward Self-Stigma TB in Surakarta}

\author{
Ignes Widowati*, Balgis, Sri Mulyani \\ Public Health Department of Medical Faculty Sebelas Maret University, Surakarta, Indonesia \\ *Corresponding Author: \\ Ignes Widowati \\ E-mail: ineswii28@gmail.com
}

\begin{abstract}
Tuberculosis (TB) infection in Indonesia has not been completely eradicated. It is challenging for those who suffer from TB to be away from self-stigma. This study aimed to determine the relationship between age factors, gender, and a history of comorbid diseases related to self-stigma. This was a cross sectional study using a Tuberculosis Stigma Assessment questionnaire. Total 50 respondents were obtained by purposive sampling technique. Inclusion criteria are TB patients or former patients aged 18 years to the elderly, male and female, without or having a history of comorbidities (HIV \& DM). Quantitativequalitative analysis, univariate and bivariate tests using Pearson Correlation and Chi Square were employed. Based on the Pearson correlation test there were no relationships between age and stigma, adolescent $(p=0.506)$, adult $(p=0.732)$, and elderly $(p=0.539)$,. Through Chi Square test, there was no relationship between the gender and stigma $(\mathrm{p}=0.520)$. Likewise, a history of comorbid disease with TB stigma which p-value 0.537 did not show any relationship. Quantitatively, $78 \%$ of respondents were stigmatized, where respondents tend to be shy and not open about their TB status. There were $78 \%$ of respondents were stigmatized but no significant relationships between age, gender, and history of comorbid diseases on TB self-stigma.
\end{abstract}

Keywords : Self-stigma; TBC; age; gender; comorbid diseases.

\begin{abstract}
Abstrak
Infeksi Tuberkulosis (TBC) di Indonesia belum tereradikasi sempurna. Penderita TBC seringkali sulit terlepas dari self-stigma. Penelitian ini bertujuan untuk mengetahui hubungan faktor usia (remaja, dewasa, dan lansia), jenis kelamin, dan riwayat penyakit komorbid dalam memengaruhi self-stigma. Penelitian cross sectional study menggunakan kuisioner Tuberculosis Stigma Assessment. Sebanyak 50 responden didapatkan dengan teknik purpossive sampling. Kriteria inklusi penderita atau mantan TBC usia 18 tahun hingga lansia, pria dan wanita, serta tanpa komorbid atau memiliki riwayat komorbid (HIV \& DM). Dilakukan analisa kuantitatif - kualitatif, uji Univariat serta Bivariate dengan teknik Pearson Korelasi dan Chi Square. Berdasarkan uji korelasi pearson tidak terdapat hubungan antara usia dengan stigma, usia remaja $(p=0,506)$, usia dewasa $(p=0,732)$, dan lansia $(p=0,539)$. Melalui uji Chi Square tidak ada hubungan antara jenis kelamin dengan stigma (p-value 0.520). Begitu pula riwayat penyakit komorbid dengan stigma TB dengan p-value 0.537 juga tidak menunjukkan hubungan. Secara kuantitatif sebanyak $78 \%$ responden terstigma, dimana responden cenderung malu dan tidak terbuka tentang status TBCnya. Terdapat $78 \%$ responden terstigma namun tidak terdapat hubungan signifikan antara faktor usia, jenis kelamin, dan riwayat penyakit komorbid terhadap self-stigma TBC.
\end{abstract}

Kata kunci: Self-stigma; TBC; usia; jenis kelamin; penyakit komorbid 


\section{Introduction}

Infectious disease Tuberculosis (TB) prevalence is still in the top rank in the infectious diseases' problems in Indonesia which has not been completely eradicated. According to WHO data in 2018, Indonesia was ranked 5th in the highest number of TB and TB/MDR cases, while Indonesia's TB-HIV cases were ranked 7th in the world (1). In 2019, Indonesia's position rose to the third rank after China and India with an estimated 845,000 TB cases while the number of notified TB cases was $543,874(2)$.

Tuberculosis has negative impacts on health also reduces the patient's immunity makes their condition get worse, even turn to other complications such as HIV/AIDS, malnutrition, and is closely related to history of comorbid diseases such as Diabetes Mellitus. In addition, TBC impacts on social life, creates community stigma even results social isolation. The existence of this stigma becomes a burden for TB sufferers which causes many patients do not want to be found out if they have TB as fear of being stigmatized. This leaves many patients undiagnosed and becomes a source of transmission for others so that the TB problem in Indonesia is not resolved.

Beside stigma from other people (enacted stigma), there also (self-stigma) which appear from theirselves, where they devaluate, ashamed, think negatively about something that has happened to them or due to external stigma (3). There are several factors could affect the response of TB sufferers in facing stigma, namely are age, gender, level of education and knowledge about TB, access to health, history of comorbid diseases, and so on. These factors could impact on the patient's psychological condition, healing progress, and motivation to recover. In addition, several conditions such as the presence of comorbid diseases further add to the stigma of the community, eventually TB sufferers tend to close themselves and be isolated. This also makes people reluctant to check themselves for fear of being stigmatized by the community, so that the discovery of TB cases in Indonesia and Surakarta in particular is still low.

In a study of Age and Race Differences of Self Esteem which data collected using Rosenberg's Scale of Global self esteem that measured vary in time told that age significantly correlated with self-esteem (4) where fluctuated self-esteem condition over the age could influencing self-stigma level among patients. While in TBC-Related Stigma study in Dalian China, a cross sectional survey where data collected using questionnaire to measure stigma that was designed by relevant literature and consultations with experts in related fields revealed that female patients were more likely to have high level of stigma than men where they were discriminated, social exclusion, and influencing marital prospect (5). Also in patients who having TBC and comorbidities such as HIV, could worsen their self-stigma level (6).

Due to the problems and the resulting impact, it is necessary to remove the stigma. Therefore, the researchers wanted to conduct research on the relationship between age, gender, and history of comorbid disease in TB patients in dealing with TB stigma in the Surakarta community. The purpose of this study was to examine how far the factors of age, gender, and history of this comorbid disease affect the response of TB patients in dealing with stigma, then find out how these TB sufferers respond to stigma and find out what stigma they have received. 


\section{Methods}

This study was an analytical observational study with a cross sectional study approach using purpossive sampling techique to collect the data. This study was conducted in 11 community health centers representing 5 sub-districts in Surakarta. The data of both TBC active patients and former TBC patients who were diagnosed from 2018 until 2021 were collected and selected depend on specified criteria. TB or former TBC patients aged 18 years old untuil elderly, women and men, without comorbidities or having comorbidities (we only focus on HIV and DM) were included. Total subjects were 80 respondents, which 30 respondents were used for questionnaire validity and reliability test, while 50 respondents for study analysis.

The instrument data collection using Tuberculosis Stigma Assessment which is developed by Stop $T B$ Partnership by Van Rie that we has translated them to Bahasa Indonesia. This assessment or questionnaire has 3 sections ( $\mathrm{A}, \mathrm{B}$, and $\mathrm{C}$ ) which each of them contains separate measurement tools. The A section contains 9 statements to measure how do respondents thoughts and feel about their TBC conditions, as illustrated in Figure 1 as $\mathrm{X} 1-\mathrm{X} 9$ to describe each point statement in section A. X1-X9 are written to describe each statement in questionnaire. There are:

$\mathrm{X} 1$ :I feel hurt because of other reactions toward my TB condition.

X2: I have lost/have been shunned by friends or relatives when I tell about my TB

X3: I feel alone

X4: I am afraid to tell other people (outside family members) that I have TB

X5: I am afraid to go to TB clinic/hospital because communities may know that I have TB

X6 : I am scared to tell others I have TB because they may thin I also suffer HIV/AIDS

X7: I feel guilty about suffering fromTB because it is a burden for my family

$\mathrm{X} 8$ : I choose carefully to anyone to talk about TB that I suffered (only tell to certain people)

X9 : I am afraid to tell about my TB to my family

Beside the statements there are four Likert Scale to measure self-stigma's level of respondents ( $1=$ strongly disagree, $2=$ disagree, $3=$ agree, $4=$ strongly agree). The B section contains of 7 questions to ask whether respondents have ever felt or obtained community stigma and where repondents obtained the stigma. Last, the C section contains of 3 descriptive question to let respondents tell about their TBC treatment and stigma experiences in detailed description. Beside those sections, sociodemographic characteristic form was added, involving questions demographic characteristics (age, gender, work, education, and income rate per month) also data of current TBC status. The cronbach alpha was 0,720 , so this assessment is reliable to used.

We collected the data by online to prevent the coronavirus spreading, thus we contacted respondents' phone number one by one then sent the questionnaire in the form of googleform. The instruction and informed consent was available inside gform, so respondents who refused to participate were excluded from this study. We guided the respondents to help them answer the questions to minimalize missinterpretation.

Data obtained from the sample were analyzed using SPSS 25.0 version. 
Univariate analysis were done to know frequencies and percentages of sociodemographic data and each variables. Bivariate analysis using pearson correlation and chi-square test were performed to examine the significance correlation between each variables. In addition we presented quantitative and qualitative analyses to examine the findings of this study.

\section{Results}

Sociodemographic data of respondents were presented in table 1 , including data on recent education, occupation, income, latest diagnosis, and treatment status at the time of the study. The majority of respondents in this study received the latest education equivalent to high school as many as 23 people. The most jobs undertaken by respondents were factory workers as many as 10 people, while the income of most respondents were below the minimum wage for Surakarta city. When we asked the respondents, majority of patients had recovered or were called ex-TB as many as 32 people, on average, they had finished treatment during the last year.
Meanwhile in table 2, talked about frequency distribution of respondents in this study. A total of 50 respondents were grouped into 4 age categories, namely: adolescent age (17-25 years), adult age (26-45 years), pre-elderly age (46-55 years), and elderly age (56->65 years). , where the most were adult respondents as many as 25 people, dominated by women as many as 28 people. This is in accordance with WHO which stated that the majority of TB patients are adults of productive age (7). However, for the gender dominance of the respondents in this study were women, it's not in accordance with several research journals such as in Sari, 2018 and Aryal, et.al, 2012 where TB respondents were more likely to be male due to smoking risk factors, work environment factors, and the possibility of drinking alcoholic beverages $(8,9)$. The majority of $\mathrm{TB}$ respondents here were without comorbidities, but for respondents with TB-DM there were 7 people while TBHIV was 1 person only who agree to participate. Based on the scores from the STP TB Van Rie questionnaire, the most respondents scored above 18 , so 39 people were classified as stigmatized while 11 people were not stigmatized.

able 1. Sociodemographic Characteristics

\begin{tabular}{lcc}
\hline Characteristics & Frequencies & Percentages \\
\hline Gender & & \\
Female & 28 & $56 \%$ \\
Male & 22 & $44 \%$ \\
\hline Age & & \\
$18-25$ & 9 & $18 \%$ \\
$26-45$ & 25 & $50 \%$ \\
$46-55$ & 12 & $24 \%$ \\
$>56$ & 4 & $8 \%$ \\
\hline Education & & \\
Uneducated & 8 & $16 \%$ \\
Elementary school & 11 & $22 \%$ \\
High school & 23 & $46 \%$ \\
Bachelor & 4 & $8 \%$ \\
\hline
\end{tabular}




\begin{tabular}{|c|c|c|}
\hline \multicolumn{3}{|l|}{ Work } \\
\hline Salesman & 6 & $12 \%$ \\
\hline Business & 3 & $6 \%$ \\
\hline Factory workers & 10 & $20 \%$ \\
\hline Drivers & 3 & $6 \%$ \\
\hline Teacher & 4 & $8 \%$ \\
\hline Employee & 8 & $16 \%$ \\
\hline Odd job & 1 & $2 \%$ \\
\hline Student & 2 & $4 \%$ \\
\hline Retired & 1 & $2 \%$ \\
\hline Unemployed & 8 & $16 \%$ \\
\hline \multicolumn{3}{|l|}{ Income } \\
\hline No income & 9 & $18 \%$ \\
\hline$<$ Rp.2.500.000 & 27 & $54 \%$ \\
\hline Rp. 2.500.000 & 3 & $6 \%$ \\
\hline >Rp. 2.500 .000 & 7 & $14 \%$ \\
\hline \multicolumn{3}{|l|}{ Current Diagnose } \\
\hline Pulmonary TBC & 15 & $30 \%$ \\
\hline Extra-pulmo TBC & 2 & $4 \%$ \\
\hline MDR-TBC & 1 & $2 \%$ \\
\hline Recovered & 32 & $64 \%$ \\
\hline \multicolumn{3}{|l|}{ Treatment Status } \\
\hline Completed $>1$ year ago & 13 & $26 \%$ \\
\hline Already done this past year & 25 & $50 \%$ \\
\hline Undergoing treatment & 12 & $24 \%$ \\
\hline \multicolumn{3}{|l|}{ Comorbidities } \\
\hline Diabetes Mellitus & 7 & $14 \%$ \\
\hline HIV & 1 & $2 \%$ \\
\hline Without comorbid & 39 & $78 \%$ \\
\hline Others & 3 & $8 \%$ \\
\hline \multicolumn{3}{|l|}{ Self-Stigma } \\
\hline Not stigmatized & 11 & $22 \%$ \\
\hline Stigmatized & 39 & $78 \%$ \\
\hline Total & 50 & $100 \%$ \\
\hline
\end{tabular}

Table 2. Relationship between Age (Adolescent, Adult, and Elderly), Gender, and Comorbidities in TB Patients toward Self-Stigma TB in Surakarta

Independent variable Dependent variable $\begin{gathered}\text { Correlation } \\ \text { coefficient }\end{gathered}$ P-value (sig.)

\begin{tabular}{|c|c|c|}
\hline Adolescent & Self-stigma & $-0,256$ \\
\hline Adult & & $-0,072$ \\
\hline Elderly & & 0,160 \\
\hline
\end{tabular}

Gender

Self-stigma

$0,520^{\mathrm{b}}$

Comorbidities

(HIV\& DM)

Self-stigma

$0,537^{\mathrm{b}}$

$\mathrm{a}=$ Pearson correlation $\mathrm{b}=$ Chi Square 
Table 3. The results of the quantitative scores of respondents' answers to the questionnaire

\begin{tabular}{lccc}
\hline \multicolumn{1}{c}{ Categories } & Stigmatized & Non stigmatized & Frequencies \\
\hline Age Group & & & \\
Adolescent (18-25 y.o) & 9 & 0 & 9 \\
Adult (26-45 y.o) & 17 & 8 & 25 \\
Elderly (>46 y.o) & 13 & 3 & 16 \\
\hline Gender & & & \\
Female & 22 & 5 & 27 \\
$\quad$ Male & 17 & 6 & 23 \\
\hline Comorbidities & & & 7 \\
DM & 5 & 2 & 1 \\
HIV & 1 & 0 & 50 \\
\hline \multicolumn{1}{c}{ Total } & 39 & 11 & \\
\hline
\end{tabular}

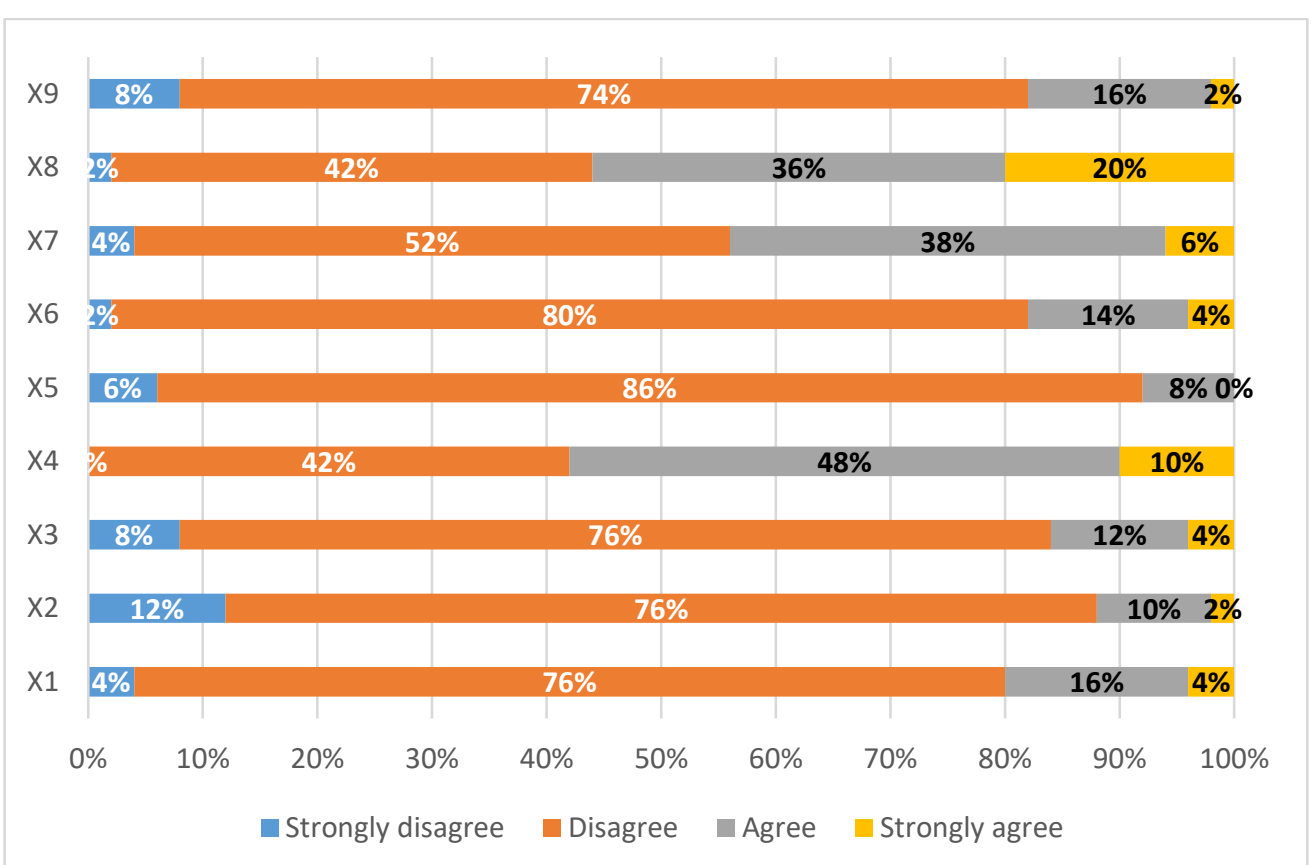

Figure 1. Percentage of respondents' answers to each item of the questionnaire questions

The results of the Pearson test for the adolescent age group, $\mathrm{p}$ value $=0.506$, the adult age group, $\mathrm{p}=0.732$, and the elderly group $\mathrm{p}=0.539$. All three had $\mathrm{p}$-value more than 0.05 , so it can be concluded that the age variable for adolescents, adults, and the elderly were not significant with self-stigma. Besides, gender and comorbidities obtained p-value 0.520 and 0,537 , where both are greater than 0.05 so there were no relationship between the two variables.

\section{Relationship between age and self- stigma of TB patients}

In the bivariate test of adolescent age (18-25 years) there was no relationship between adolescent age and self-stigma. According to the previous theory, Neff and McGehee (2010), during adolescence there were several distinct pressures, such as pressures when searching for selfidentity, pressures for academic performance, need to be popular, the desire to be accepted, feeling fit in an appropriate social group, role and environmental conditions that cause social pressure to make adolescent emotional tension higher where this could affect selfesteem (10). As Maharjan, et.al, 2019 said self-esteem was related to self-stigma, the 
lower the self-esteem, the higher the selfstigma. Thus during puberty, where emotions fluctuated, adolescents were vulnerable to have low self-esteem (11) so they were vulnerable about self-stigma. However, the results of this study did not agree with the theories above.

Meanwhile, the bivariate test for adults (26-45 years old) toward selfstigma also showed no significant relationship. This did not correlate with previous theories, such as in Jahja, 2011 where adults began to stabilize their emotions and showed authority so they could be wiser, think longer, and were not easily influenced by stigma (12). In addition, from research by Shaw, et.al, 2011 said at the age of young adults (25 years) experience increasing of selfesteem and when entering the age of mild life (45 years), self-esteem tended to be stable which could affect adults in responding stigma (4).

Likewise in the elderly who did not show any significant relationship between the self-stigma of tuberculosis, which was not in accordance with the theory of Eisdofer, 1997 in Johana 1994 which said in the elderly there was a degenerative process, the body was weakened and susceptible to disease especially if the elderly were exposed to Tuberculosis and the stigma of society, it would be easier to make them down and lose motivation. Self-esteem in the elderly also began to decline (4) . In the study of Griffiths, et.al, 2008 it was also found that self-stigma was significantly higher in older patients (13), but the above study did not agree with the results of this study.

The conclusion of this study was adolescents, adults and the elderly were not significant with self-stigma. According to Widiyatun, 1999 self-stigma was influenced by intrinsic factors such as age, gender, maturity level, experience, physical condition and mental health, as well as extrinsic factors including family factors, friend support, environment, socio-culture, and community norms that applied in the area (14). So besides being influenced by age (intrinsic), extrinsic could be the answers. As in the study of Abdisa, et.al, 2020 which examined selfstigma in Mental Illness patients, the results showed that family, friend, and environmental support significantly affected self-stigma, where patients who received social support tended to have a good prognosis and avoid by self-stigma (15).

\section{Relationship between gender and self- stigma of TB patients}

There was no significant relationship between gender and self-stigma of TB patients in bivariate analysis which showed $\mathrm{p}$ value $=0.520539$ (greater than 0.05 ). According to the gender difference hypothesis, that were, physically and psychologically, men and women had their own characteristics, differences in emotional management between men and women affected their mindset, how to express emotions, and how they behave, thus influencing the perspective on stigma.

In the study of Mirowsky and Ross, 2000 women reported more symptoms when experiencing distress, depression, and anxiety than men (16). In addition, men had a habit of hiding what they felt more than women who were more expressive of their emotions so easy for self-stigma to occur (17). However, the results of this study did not agree with the research above, because self-stigma can be influenced by extrinsic factors as previously described. According to, Jing Teo et.al.2020 explained TB patients had courage to face their illness because of family support, friends, and other TB survivor made them stronger in facing stigma (18).

In addition, there were social factors could affect the stigma of TB patients, 
where TB respondents who lived in urban areas had higher average stigma value than those who lived in rural areas, as in urban areas respondents more secretive, did not want others to know if they were suffering from TB than residents of rural areas who were more indifferent to TB (19), as is the case with research by Mushtaq, et.al. 2011 which said the majority of TB respondents in urban areas felt embarrassed if they were found to have TB compared to respondents in rural areas (20). Stigma in TB patients was also more prevalent in respondents of working age (20-50 years old) because respondents often felt afraid and embarrassed if their coworkers know about their TB disease and frequently stigmatized (shunned) by coworkers if caught (21)

\section{Relationship History of Comorbid Diseases (HIV \& DM) with Self-stigma of TB patients}

Bivariate analysis between comorbid disease variables (HIV \& DM) and selfstigma showed no significant relationship. In our hypothesis, comorbid diseases (HIV \& DM) had a relationship with self-stigma as TB patients with comorbidities felt negative impacts, both physically (sick) and the stigma imposed on them, patients tended to feel burdened, tended to be alone and blame themselves. As research by Yuyun et al, 2011 said most of the HIV respondents were still afraid of their HIV status being known by others due to afraid of being stigmatized and ostracized by society (6). Likewise, DM sufferers who felt the psychological impact since being diagnosed with Diabetes Mellitus, where every day he lives with DM, of course the patient would feeling discouraged, stressed or even depressed (22).

However, the results of the analysis of this study did not agree with the theory above, because it could be affected by several factors. First, lack number of participants in this study due to since pandemic strikes, TBC findings in all health centers were decreased also some respondents refused to participate, therefore the number of respondents was quite small. TB-DM and TB-HIV respondents in this study, namely 7 people (TB-DM) and 1 person (TB-HIV), the results might not be significant. Although some journals, especially those with TBHIV, said to have higher levels of anxiety and were significantly associated with stigma (23) and TB-HIV sufferers felt more embarrassed and often criticized for suffering from HIV which was considered to be contagious (18).

In addition to the lack of research respondents, there could be other external factors affected self-stigma, as in the study of Botchsway, et.al. 2021 regarding stigma in people with diabetes in Ghana found there was no significant difference between patients with low stigma or high stigma, one of which was influenced by the factor of family support (social support) where respondents with low selfstigma were significantly positively correlated with the presence of high social support. Height (24) .

From the table 3 could be seen as a whole based on the results of the questionnaire scores, respondents with stigmatized scores were much higher than non-stigma scores. In the age category, both the category of adolescents, adults, and the elderly, the stigmatized scores more than those who were not stigmatized. In the gender category, women scored more stigmatized than men, and 5 people with comorbid DM were stigmatized and 1 person with HIV.

If a comparison was made, according to the questionnaire score as many as $78 \%$ of respondents were stigmatized, but in the SPSS, analysis test the relationship between independent variables and selfstigma was not proven to be significant. This could be due to the fact that the 
number of respondents who represented each variable in this study was quite small, so could not represent the actual relationship between the two variables. As in the adolescent age category which only got 9 people, and in the comorbid disease variable where TB-DM was only 7 people and TB-HIV was only 1 person. So even though the score was stigmatized, could not show any relationship.

In the other hand, there were external factor could made no significant results among independent variables, which there were no treatment differences (psychological treatment to reduce selfstigma) among variables ages (adolescent, adult, and elderly), gender (woman and men), and comorbid disease of Diabetes Mellitus, except for HIV where the TBHIV patients will get more attention and monitoring both physical and mental health. The public health center have some programs to controlling both self-stigma in patients also community stigma, such as, conduct counseling when starting TB treatment also during medical control, but most of public health center give same counseling treatment to TB patients, which no spesific differences on stigma TB treatment toward those independent variables, so this could be another reason this relationship was not significant.

The discussion contained a discussion that connected and compared the research results with the theory being tested and the results of previous research. The discussion could end by mentioning the limitations of the study and suggestions for further research.

In this questionnaire there were 9 question items which include questions with points using a Likert scale system (1 $=$ strongly disagree, $2=$ disagree, $3=$ agree, 4 = strongly agree) accompanied by questions with description answered for respondent shared their opinion about the experience of stigma. The following were a review of respondents' answers.
The following presents the data based on Figure 1 which the percentage of respondents' answers to the questionnaire from items X1-X9, dominant respondents answered agree on items $\mathrm{X} 4, \mathrm{X} 7$, and $\mathrm{X} 8$. In item X4 with the question "I am afraid to tell other people (outside family members) that I have TB", the most respondents answered point 3 (agree) and the second most was point 2 (disagree).

The followings were a description of the patient's answers agree:

“...And because I'm ashamed, it's also impossible to tell my friends/others that I'm sick with TB, I'm afraid of being shunned. So I don't expose my TB, only to my family. I am very careful and afraid to relate to other people" (DA, 21 years old)

"I didn't tell my parents and in-laws for fear of being worried because I was old. I don't tell my big family and neighbors, only my wife and children who know." (Jo, 39 years old)

However, there are also patients who did not agree:

"I am an open person, so everyone knows that I have tuberculosis and no one stays away. I just have fun and don't think negatively" (SL, 25 years old)

From the description above, many respondents choose to only talked about TB to certain people because they were afraid of being shunned, ostracized, and fear to be a burden on their minds. However, some patients also did not mind telling their condition, it could be influenced by the personality factor of someone who were open or believed that people around support them.

In item X7 with the question "I feel guilty about suffering from TB because it is a burden to my family" the most respondents gave a score of 2 (disagree) as much as $52 \%$ and a score of 3 (agree) 38\%. Here's the description: 
"I also feel very guilty about suffering from tuberculosis, because at home I live with mother only, I as the breadwinner for family while my mother is sick, so I feel guilty for suffering from tuberculosis." (Mu, 20 years old)

"I feel guilty how come I got TB" (Madam, 51 years old)

"I feel guilty that I got TB, maybe because I smoked and met a lot of people at work. Meanwhile at home, my cousin is still young, it's a shame if he catches it, so I keep my distance and wear mask also my own spoon." (SL, 25 years old)

However, there are also those who disagree with this statement:

"I don't feel bad talk/fear/guilt because my principle of being sick is from Allah (God), so I just accept it and treat it until it heals." (So, 51 years old)

"My husband always supports me in reminding me to take medicine and maintain my diet, so I feel motivated." (Ro, 31 years old)

From the respondents' descriptions, they guilty for suffering from TB because they felt sorry for family members who lived in the same house as the respondent due to fear of being infected. However, some respondents disagree because respondents received support from their families so they were motivated, some were sincere and resigned that all the illnesses they suffered were God's destiny so there was nothing to regret.

Finally, the $\mathrm{X} 8$ item. with the statement "I choose carefully to anyone to talk about the TB that I suffer (only tell certain people)" the most patients answered point 2 (disagree) as much as $42 \%$ and the second most was point 3 (agree) as much as $36 \%$ with the following description:

"During the time I was sick with TB, I was afraid to tell other people, afraid to be

shunned/discussed negatively. So my family and I don't tell anyone, even if we only tell people who are really close and can be trusted." (D, 22 years old)

"Never tell my neighbors because I am afraid that the neighbors will know it (as I live in the village)" ( $\mathrm{F}, 26$ years old)

"I don't get stigmatized for being picky about stories about TB, so only certain people know." ( $\mathrm{Su}, 52$ years old)

However, there are also patients who disagree with this statement:

"My family and neighbors are supportive; there's no avoiding and I don't cover up." (De, 43 years old)

"The neighbors around here are supportive people, they don't isolate/dissolve them, they even support them so they can get better." (Aug, 41 years old)

From the description above, that respondents were scared to tell about TB (only tell certain people) because they were afraid of being shunned, ostracized, and getting bad words. However, respondents who disagree have a reason that the patient felt his family and their environment (neighbors/friends) won't isolate the respondent.

\section{Discussion}

This research study aims to see the form of self-stigma that occurs in TB patients in Surakarta associated with age, gender, and history of comorbid disease with 50 respondents as subjects where quantitatively obtained 39 or $78 \%$ respondents were stigmatized. This result was bigger than the findings in the TBC self-stigma study in Cambodia that used a similar questionnaire which stigmatized percentage of more than $50 \%{ }^{18]}$. The results showed there was no significant relationship between age, gender, and comorbid disease (HIV \& DM) variables on self-stigma, but quantitatively $78 \%$ of respondents were stigmatized. This 
section will combine discussion of quantitative with qualitative findings.

The answers and scores given by respondents to the 9 questions above vary greatly. Some gave an agree score to all question items, some only gave a score of 3 (agree) to 2-3 items, some even gave only 1 item a agree score, but even though only 1 out of 9 items was given a score of agree, the total score was quantitative already stigmatized. Therefore, the answers and scores of respondents vary widely. However, from the nine items above, the item that was chosen by the most respondents with a score of agreeing was the question item no. 4 "I am afraid to tell other people (outside family members) that I have TB", item no. 7 "I feel guilty for suffering from TB because I am a burden to my family" and item no. 8 "I choose carefully to tell anyone about my TB (only tell certain people)". Respondents of adolescent, adult, and elderly age, both female and male, and a history of comorbid DM and HIV, each dominantly answered agree on item no. 4 , 7 , and 8 . Thus, in this study, the dominant TB respondents felt stigmatized (selfstigma) due to closing themselves off from the outside environment because of shame and fear of being stigmatized by society.

In item no.4, 58\% of respondents answered agree if they were afraid to tell other people (outside family members) that they had TB. According to the respondent's confession, they were scared other people would find out about their TB status because they would be being shunned, given a negative stigma from society, or even losing their job. Thus many respondents were silent (not telling) to other people except family/close friends who can be trusted. Some of them even did not admit that they had TB when asked. This was similar to the research of Mushtaq, 2011 where the majority of TB respondents, especially those living in Urban areas covered his TB status (20).
In addition, in Abioye, et.al, 2011 also explained many TB patients covered their TB status from the community in anticipation of external stigma, and some who told their TB status are stigmatized (23). Whereas in TB-HIV patients, respondents never told others they had HIV, for fear of being discriminated, as in Cremers, 2015 where TB-HIV sufferers were associated with immoral behavior (25). The existence of self-stigma caused sufferers to fear being a source of transmission and being discriminated against/bullying from the community. However, by not telling other people, most of the respondents did not feel stigmatized from the community, according to the qualitative discussion as many as $80 \%$ of people did not feel stigmatized because no one else knew the respondent had TB.

Furthermore, $44 \%$ of respondents felt guilty for suffering from TB as they felt were a burden on their family. As it's known TB was highly contagious (26) made sufferers afraid of transmitting it to their families, besides many sufferers couldn't work during treatment so their income for family needs was reduced, as Courtwright research, 2010 that TB sufferers, especially men, often lose their jobs due to TB (27). But on the other hand, $80 \%$ of respondents in this study received positive support from their families, therefore even though they felt guilty, their families still supported their treatment, where family support and closest people played an important role in supporting the treatment and recovery of TB patients (28).

Finally, $56 \%$ of respondents chose carefully to tell anyone about TB (only told certain people). The majority of TB sufferers only told their TB status to the closest people, such as family, lovers, close friends, close relatives, or people who had an interest in knowing about their condition (29). Due to TB sufferers scared of being negatively stigmatized by others 
and treated unfavorably, made them tended to close themselves off and hide their identity (8).

In addition to the three items above, as many as $20 \%$ of respondents were found to have been hurt due to being stigmatized from outside, where as much as $2.4 \%$ received stigma at home, $3.7 \%$ received stigma at work and hospitals/health centers, and $12.2 \%$ received stigma at home. Respondents said they were shunned at work and by their neighbors because they were afraid of being infected, as well as being discriminated against by health workers when they wanted to check at the health center.

Due to still many TB respondents who have self-stigma that masks the identity of the condition suffered from the surrounding community, efforts are needed to overcome self-stigma in TB patients because the resulting consequences could worsen treatment results, trigger greater transmission, and facilitate the occurrence of multiresistant drug TBC. Therefore to eliminate selfstigma, it is necessary to empower them with regard to their TB status, such as counseling by health workers and discussion forums between patients and their families to support TB patients (30).

\section{Conclusion}

The results showed there was no relationship between adolescent age ( $\mathrm{p}$ value 0.506), adult age (p-value 0.732), elderly age ( $p$-value 0.539$)$, gender (pvalue 0.520 ), and history of comorbid diseases ( $p$-value 0.520). p-value 0.537) toward TB self-stigma. However, in quantitative terms, $78 \%$ of respondents felt stigmatized where the dominant respondents tended to feel ashamed and cover up their TB status from the surrounding environment in order to avoid community stigma.
Because there are still many TB respondents who have self-stigma that masks the identity of the condition suffered from the surrounding community, efforts are needed to overcome selfstigma. There needs empowerment in relation to their $\mathrm{TB}$ status, such as counseling by health workers and discussion forums between patients and their families to support TB patients on a regular and scheduled basis.

In addition, it is necessary to educate the community about knowledge of TB disease and the impact of stigma on TB sufferers, hope the community will be aware the importance to eliminate negative stigma towards TB sufferers. If this is carried out comprehensively, both community stigma and self-stigma for TB sufferers would be eliminated and help reduce TB cases in Indonesia.

\section{Acknowledgment}

The researcher expresses gratitude to Allah SWT, the Almighty God, with whose permission this research can be completed properly. Then the researcher would like to thank the parents who always give their prayers and give the best for the researcher. In addition, to dr. Balgis and Mrs. Mulyani as supervisors who guide the author so this research could be better. And lastly, thanks to fellows for the motivation given.

\section{References}

1. World Health Organtization (WHO). Global TB Report 2018. Paris : France.

2. World Health Organtization (WHO). Global TB Report 2019. Paris : France.

3. Alison J Gray, MRCPsych. Stigma In Psychiatry. Journal of The Royal Society of Medicine 2002; 95(2): $72-$ 76.

4. Shaw, B. A., Krause, N., Liang, J. and Bennett, J. Tracking changes in social 
relations throughout late life. Journals of Gerontology: Psychological Sciences and Social Sciences 2011; 62B, 2, S90-9.

5. Chen, et.al. Tuberculosis-related Stigma and It's Determinants in Dalian, Northeast China: a crosssectional study. BMC Public Health 2021; 21(6).

6. Yuyun, Y, Rini,S.H dan Aryastami.N.K. Faktor - Faktor Pendukung Kepatuhan Orang Dengan HIV/AIDS (Odha) Dalam Minum Obat Antiretroviral Di Kota Bandung Dan Cimahi. Pusat Teknologi Intervensi Kesehatan Masyarakat, Badan Litbangkes, Pusat Humaniora, Pemberdayaan Masyarakat dan Kebijakan Kesehatan, Badan Litbangkes Buletin Peneliti Kesehatan 2011; 42(2): 72 - 83 73. Bandung.

7. World Health Organtization (WHO). Global TB Report 2014. Paris : France.

8. Sari Yunita. Gambaran Stigma Diri Klien Tuberkulosis Paru (TB Paru) Yang Menjalani Pengobatan Di Puskesmas Malingping. Media Ilmu Kesehatan 2018; 7(1).

9. Aryal S., Badhu, A., Pandey, S., Bhandari, A., Khatiwoda, P., Khatiwada, P., \& Giri, A. Stigma related to Tuberculosis among patients attending DOTS clinics of Dharan Municipality. Kathmandu Univ Med J 2012;37(1)48-52.

10. Neff, K. D., dan McGehee, P. SelfCompassion and Psychological Resilience Among Adolescent and Young Adults'. Self and Identity 2010.

11. Bach \& Szivos., S. E. Social comparison, stigma and mainstreaming: the self-esteem of young adults with a mild mental handicap. Mental Handicap Research 2010; 6(3): 217-236. DOI: 10.1111/j.1468-3148.1993.tb00054.x.

12. Jahja. Pertumbuhan dan perkembangan remaja. Jakarta: Salemba Medika; 2010.

13. Kathleen M Griffiths,Helen Christensen, Anthony F Jorm. Predictors of Depression Stigma. BMC Psychiatry 2008; 8(25).

14. Widayatun TR. Behavioral science. Jakarta: CV. Sagung Seto. 1999.

15. Eba Abdisa, Ginenus Fekadu, Shimelis Girma, Tesfaye Shibiru, Temesgen Tilahun, Habib Mohamed, Aaga Wakgari, Amsalu Takele, Milkias Abebe,Reta Tsegaye. Self-stigma and medication adherence among patients with mental illness treated at Jimma University Medical Center, Southwest Ethiopia. International Journal of Mental Health System 2020;14(56).

16. Mirowsky, J., \& Ross, C. E. Social causes of psychological distress. New York: Aldine de Gruyter 2003.

17. Hsiu-Lan Cheng, Cixin Wang, Ryon C. McDermott, Matthew Kridel, Jamey Leeanne Rislin. Self-Stigma, Mental Health Literacy, and Attitudes Toward Seeking Psychological Help. Journal of Counseling and Development 2018; (96) : DOI: 10.1002/jcad.12178.

18. Jing Teo,et.al. Characterizing and Measuring Tuberculosis Stigma in the Community: A Mixed-Methods Study in Cambodia. Open Forum Infectious Diseases 2020; 7(10)

19. Oladele, et.al. A Comparative Study of Knowledge, Attitude, and Determinants of TuberculosisAssociated Stigma in Rural and Urban Communities of Lagos State, Nigeria. Tuberculosis Research and Treatment 2020; doi: 10.1155/2020/1964759

20. Mushtaq ,et.al. Urban-rural Inequities in Knowledge, Attitudes and Practices Regarding Tuberculosis in Two Districts of Pakistan's Punjab Province. International Journal of Equity in Health 2011; 8(4)

21. Fischer, A. H., Rodriguez Mosquera, P. 
M., van Vianen, A. E. M., \& Manstead, A. S. R. Gender and Culture Differences in Emotion. Emotion 2004; 4(1): 87-94. https://doi.org/10.1037/15283542.4.1.87

22. American Association of Diabetes Educator. AADE7 self-care behaviors 2014. Available at https://www.diabeteseducator.org/pati entresources/ diakses pada 18 September 2019

23. Abioye, et.al Socio-demographic determinants of stigma among patients with pulmonary tuberculosis in Lagos, Nigeria. African Health Science 2011, 11(1)

24. Marian Botchway, PhD, MPH1, Rachel E. Davis, PhD, MPH2, Anwar T. Merchant, ScD,MPH, DMD, Lambert T. Appiah, MD4, Spencer Moore, PhD, MPH. Diabetes-Related Stigma And Its Influence On Social Networks, Social Support, And Hba1c In Ghana. Original Report:Stigma,Discrimination,Health Disparities 2021; 31(1):57-66. DOI:10.18865/ed.31.1.57

25. Cremers,et.al. Assessing the Consequences of Stigma for Tuberculosis Patients in Urban Zambia. PLoS ONE 2015; 10(3): e0119861.

26. Helper Sahat P. Manalu. Faktor-Faktor Yang Mempengaruhi Kejadian $\mathrm{Tb}$ Paru Dan Upaya Penanggulangannya. Jurnal Ekologi Kesehatan 2010; 9(4).

27. Courtwright, A., \& Turner, A. N. Tuberculosis and Stigmatization:Pathways and Interventions. Public Health Reports 2010; 125(Suppl 4), 34 \pm 42 .

28. Muhardiani, Mardjan, Abrori. Hubungan Antara Dukungan Keluarga, Motivasi Dan Stigma Lingkungan Dengan Proses Kepatuhan Berobat Terhadap Penderita Tb Paru Di Wilayah Kerja
Puskesmas Gang Sehat. Jurnal Mahasiswa dan Peneliti Kesehatan 2015; 2(3).

29. E A Dodor. The Feelings and Experiences of Patients with Tuberculosis in the Sekondi-Takoradi Metropolitan District: Implications for TB Control Efforts. Ghana Medical Journal 2012; 46(4): 211-218.

30. Dedeh Husnaniyah, Mamat Lukman, Raini Diah Susanti. Faktor-Faktor Yang Berpengaruh Terhadap Harga Diri (Self Esteem) Penderita Tuberkulosis Paru Di Wilayah Eks Kawedanan Indramayu. The Indonesian Journal of Health Science 2017; 9(1). 